\title{
First record of the buff-fronted owl, Aegolius harrisii - (Cassin, 1849) (Aves - Strigidae) from the Brazilian state of Pernambuco
}

\author{
A. J. S. Oliveira ${ }^{a, b *}$ (D), L. S. Cabral ${ }^{a, b}$ (D), A. S. Silva ${ }^{a, b}$ (D), V. C. Souza $a^{a, b}$ (D), \\ S. L. Florêncio ${ }^{b}$ (i), W. R. Telino-Júnior ${ }^{a, b}$ (1) and R. M. Lyra-Neves ${ }^{a, b}$ (1) \\ aPrograma de Pós-graduação em Ecologia, Universidade Federal Rural de Pernambuco - UFRPE, \\ Rua Dom Manoel de Medeiros, s/n, Dois Irmãos, CEP 52171-900, Recife, PE, Brasil

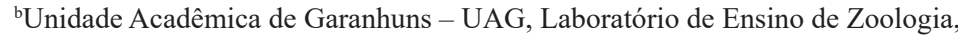 \\ Universidade Federal Rural de Pernambuco - UFRPE, Avenida Bom Pastor, Boa Vista, CEP 55296-901, \\ Garanhuns, PE, Brasil \\ *e-mail: allanjeffersonufpe@gmail.com
}

Received: June 8, 2018 - Accepted: October 8, 2018 - Distributed: February 28, 2020

(With 1 figure)

The genus Aegolius includes five species (Gill and Donsker, 2018), but only the buff-fronted owl, Aegolius harrisii (Cassin, 1849) occurs in Brazil (Piacentini et al., 2015). This species is widespread in central and eastern Brazil, being found throughout the Northeast, and also in the states of Rio Grande do Sul, Mato Grosso, Minas Gerais, Espírito Santo, Rio de Janeiro, Distrito Federal, São Paulo, Paraná, and Santa Catarina (Sick, 1997; Girão and Albano, 2010; Grantsau and Palo Junior, 2010). In the Brazilian Northeast, $A$. harrisii has been recorded in three states that border Pernambuco - Alagoas (Sick 1997), Bahia (Antas et al., 1993; Lima and Castro, 1994; Studer and Teixeira, 1994; Girão and Albano, 2010), and Ceará (Girão and Albano, 2010). Sick (1997) referred to the expected presence of $A$. harrisii in Pernambuco, although this was not confirmed by documented evidence (Farias et al., 2008). No subsequent records have been obtained of the occurrence of the species in the state.

Aegolius harrisii is of low priority for conservation (Stotz et al., 1996) and medium priority for research, although it is classified as Near Threatened (Parker III et al., 1996; Holt et al., 1999), due to its sparse distribution and the lack of data on its populations. This emphasizes the need for research on the biology of the species and its geographic distribution. A. harrisii may face local threats from the widespread devastation of its natural habitats in the Atlantic Forest, and in particular the cloud forest enclaves, known locally as "Brejos de Altitude" (Viana, 1997). It may have deleterious implications for remaining populations, due to the sensitivity of the species to habitat disturbance (Parker III et al., 1996).

The record of $A$. harrisii was obtained during fieldwork on the Fazenda Fojos $\left(-8.892458^{\circ} \mathrm{N},-36.558066^{\circ} \mathrm{W}\right)$ in one of the property's largest forest fragments, known as Camapuã (22 ha), which is close to a fragment of $150 \mathrm{ha}$, located on the neighboring property. In May 2018, the mist-netting was extended to the nocturnal period, for the capture of bats. This resulted in the capture of a buff-fronted owl on May 20th 2018. This owl was subsequently released and photographed in its natural environment. The photographic record of the specimen (Figure 1) was deposited on the Wikiaves platform site (Oliveira, 2018), under catalog number WA2978376.

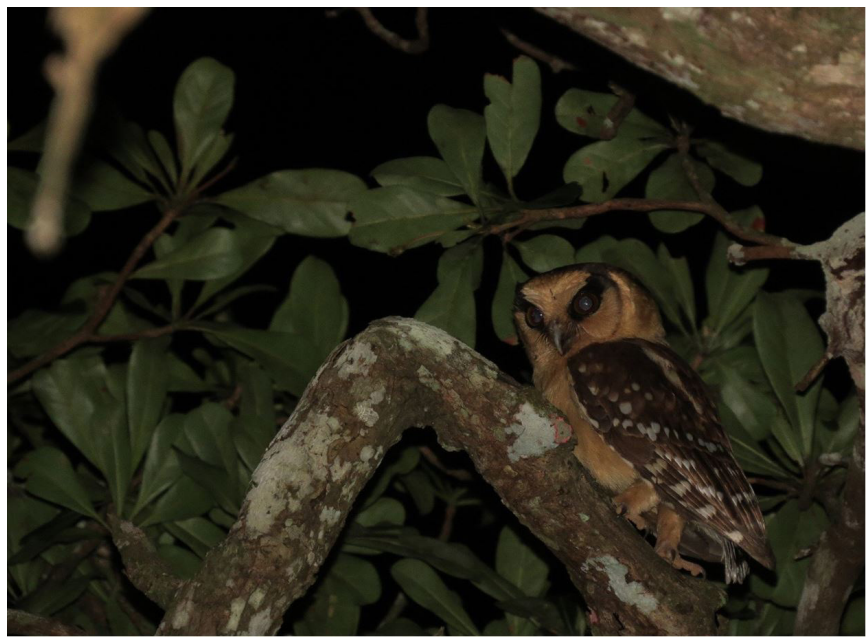

Figure 1. Aegolius harrisii recorded on the Fazenda Fojos in the municipality of Garanhuns, Pernambuco, Brazil (Photograph by A. J. S. Oliveira). 
This record confirms the occurrence of the buff-fronted owl, Aegolius harrisii, in the Brazilian state of Pernambuco, which resolves a long-standing lacuna in the inventory of the state's avian fauna. Reports of this type are important for providing basic ecological data on poorly-known species, in particular distribution records, which are essential for the development of effective environmental management strategies (Piacentini et al., 2006; Godoi et al., 2012). Records of the rare, threatened or poorly-known species from data-poor areas are essential for the understanding of the local biota and the planning of effective conservation measures (Godoi et al., 2012).

\section{Acknowledgements}

We thank to Mrs. Iara Cohin, for allowing us to conduct research on the property, and also to the Brazilian Coordination for Higher Education Training (CAPES) for financial support.

\section{References}

ANTAS, P., CÂNDIDO-JÚNIOR, J.F., REINERT, B.L. and PINHEIRO, R.T., 1993. Lista das aves da fazenda Jatobá, Correntina, BA. In: Anais do III Congresso Brasileiro de Ornitologia-Resumos, 1993, Pelotas. Pelotas: Universidade Católica de Pelotas.

CASSIN, J., 1849. Descriptions of new species of the genera Nyctale, Brehm., and Sycobius, Vieill: specimens of which are in the collection of the Academy of Natural Sciences of Philadelphia. Proceedings. Academy of Natural Sciences of Philadelphia, vol. 4, pp. 157-158.

FARIAS, G.B., PEREIRA, G.A. and SILVA, W.A.G., 2008. Lista das aves de Pernambuco. Recife: Observadores de Aves de Pernambuco.

GILL, F. and DONSKER D., 2018. IOC World Bird List, version 8.1. London: IOC

GIRÃO, W. and ALBANO, C., 2010. Sinopse da história, taxonomia, distribuição e biologia do caboré Aegolius harrisii (Cassin, 1849). Revista Brasileira de Ornitologia, vol. 18, no. 2, pp. 102-109.

GODOI, M.N., MORANTE-FILHO, J., FAXINA, C., MODENA, E.S., PIVATTO, M.A.C., MANÇO, D.D.G., BOCCHESE, R., TERIBELE, R., MARTINS-ROSA, A.L. and STAVIS, V.K.,
2012. Aves de rapina raras no estado de Mato Grosso do Sul, Brasil. Atualidades Ornitológicas, vol. 170, pp. 41-47.

GRANTSAU, R. and PALO JÚNIOR, P.J., 2010. Guia completo para identificação das aves do Brasil. São Carlos: Vento Verde.

HOLT, D., BERCKLEY, R., DEPPE, C., ENRÍQUEZ-ROCHA, P.L., PETERSEN, J.L., RANGEL-SALAZAR, J.L., SEGARS, K.P. and WOOD, K.L., 1999. Species accounts of Strigidae: Tamaulipas Pygmy-owl. In: J. DEL HOYO, A. ELLIOTT and J. SARGATAL, eds. Handbook of the birds of the world. Barcelona: Lynx Editions, vol. 5.

LIMA, P. and CASTRO, J., 1994. Ocorrência e reprodução de Aegolius harrisii na Bahia. In: Resumos do IV Congresso Brasileiro de Ornitologia, 1994, Recife. Recife: UFRP.

OLIVEIRA, A.J., 2018 [viewed 4 April 2019]. [WA2978376, Aegolius harrisii (Cassin, 1849)]. In: WIKI AVES. A enciclopédia das aves do Brasil [online]. Available from: http://www.wikiaves. com/2978376

PARKER III, T.A., STOTZ, D.F. and FITZPATRICK, J.F., 1996. Ecological and distributational data bases. Chicago: University of Chicago Press.

PIACENTINI, V.Q., ALEIXO, A., AGNE, C.E., NACHTIGALLMAURÍCIO, G., PACHECO, J.F., BRAVO, G.A., BRITO, G.R.R., NAKA, L.N., OLMOS, F. and POSSO, S., 2015. Lista comentada das aves do Brasil pelo Comitê Brasileiro de Registros Ornitológicos. Revista Brasileira de Ornitologia-Brazilian Journal of Ornithology, vol. 23, no. 2, pp. 90-298.

PIACENTINI, V.Q., GHIZONI-JUNIOR, I.R., AZEVEDO, M.A.G. and KIRWAN, G.M., 2006. Sobre a distribuição de aves em Santa Catarina, Brasil, parte I: registros relevantes para o Estado ou inéditos para a Ilha de Santa Catarina. Cotinga, vol. 26, pp. 25-31.

SICK, H., 1997. Ornitologia brasileira. Rio de Janeiro: Nova Fronteira.

STOTZ, D.F., FITZPATRICK, J.W., PARKER III, T.A. and MOSKOVITS, D.K., 1996. Neotropical birds: ecology and conservation. Chicago: University of Chicago Press.

STUDER, A. and TEIXEIRA, D., 1994. Notes on the bufffronted owl Aegolius harrisii in Brazil. Bulletin of the British Ornithologists' Club, vol. 114, no. 1, pp. 62-63.

VIANA, V., 1997. Dynamics and restoration of forest fragments in the Brazilian Atlantic moist forest. In: W.F. LAURANCE and R.O. BIERREGAARD, eds. Tropical forest remnants: ecology, management, and conservation of fragmented communities. New York: Chicago University Press, pp. 351-365. 